\title{
Изследване на носното дишане при пациенти с девиация на носната преграда
}

\author{
Пл. Недев, Г. Илиев Г, М. Милков, \\ К. Керимов, Ал. Трайковски \\ УМБАЛ „Св. Марина“ - Варна и МУ „Проф. Д-р П. Стоянов“ - Варна
}

\section{Резюме}

Носната обструкция е често срещано състояние в оториноларингологията, предимно обусловена от девиация на носната преграда. Риноманометрията е обективен метод на изследване. Ние представяме своя опит при риноманометрия и риноспирометрия при пациенти с девиация на носната преграда. Предимствата на риноспирометрията се изразяват в това, че се изследват едновременно и двете ноздри, като се предотвратява тяхната деформация.Двата метода на изследване се допълват и дават обективна оценка за планиране и провеждане на лечение, съответно на степентта на носна обструкция.

Ключови думи: риноманометрия, девиация на носната преграда.

\begin{abstract}
Nasal respiratory obstruction is a very common otolaryngologic problem, often caused by nasal septum deformities. Rhinomanometry represents a valid diagnostic support. We present our experience with rhinomanometry and rhinospirometry by patients with nasal septum deviations. Advantages related to rhinospirometry test are the most functional assessment of the patient and the possibility of a simultaneous evaluation of both nostrils without nostrils deformation. These two techniques represent a valid tool for clinicians to decide the most appropriate treatment, based on the degree of nasal obstruction.
\end{abstract}

Keywords: rhinomanometry, nasal septum deviation.

\section{Увод}

Често субективните оплаквания и предната риноскопия не са достатъчни за пълна преценка за естеството на носното дишане. От особена важност е възможността за обективизиране на назална обструкция относно поведението и резултатите от лечението и. Измерването на транзиторното налягане и въздушен поток се означава с термина риноманометрия (манометрия - измерване на налягането) и (реометрия - измерване на потока).

Общ недостатък на обективните методи за изследване произтичат от сложното устройство и физиология на носната кухина и във връзка с това несъвършенството на техническите параметри на апаратурата известна до този момент. Основното се стои в това, че измерването дава представа само за моментното състояние, докато носа е орган с динамични функции, влияещи се от много фактори в нормални условия.

Пасивна риноманометрия - измерванията се извършват след активно (форсирано) нагнетяване на въздух в носната кухина.

Активна риноманометрия - измерванията се правят по време на нормално дишане през носа, което е от по-голяма важност за практиката.

Измерване на трансназалното налягане. То се измерва чрез следните три метода:

1. Задна риноманометрия: перорална тръба минаваща при затворена уста към орофаринкса. И двата въздушни пътя трябва да останат отворени - палатоглосалния и палатофарингеалния. Този 
метод е подходящ за установяване на обструкция от аденоидна вегитация.

2. Перназална методика: финна трансназална тръба преминаваща по дължина по пода на носа към назофаринкса. Тръбичката се фиксира така за няколко часа. Това измерване не включва назофарингеалните пътища.

3. Предна риноманометрия: финна тръба поставена във входа на носа, или маска. Измерват се двете носни кухини поотделно. Изчисленията се правят по закона но Ом за успоредни резистори. Разместването на тръбичките или маската води до неточен резултат. Неудобство е, че дишането е само от едната носна половина. Съществува риск от аларен колапс. Увеличава се активността на аларния дилататорен мускул. Този метод е най-често използвания в практиката.

Във връзка с многото критики отправени по повод на риноманометрията в световната литература зачестяват публикациите изтъкващи други обективни методи за изследвате на носното дишане.

\section{Материал и методи}

1. Изследвани са с помощта на предна активна риноманометрия

- 72 (35 мъже и 37 жени) клинично здрави пациенти. Всички те бяха без оплаквания от носна обструкция. Липсваха анамнестични данни за носна обструкция, преболедували синуити или алергични ринити. Предната риноскопия не показа деформитети на носната преграда или друга находка предполагаща патология в носната кухина водеща до затруднено носно дишане

Целта на изследването бе да се установят нормалните риноманометрични стойности и те да се сравнят с тези при пациенти с девиирана носна преграда.

- 102 (56 мъже и 46 жени) от общо 118 оперирани по повод нарушено носно дишане дължащо се на изкривена носна преграда пре и постоперативно.

Целта бе да се да се установи как повлиява носния въздушен поток девиираната носна преграда и как се отразява хирургичната интервенция на носното дишане.

Изследването на носното дишане извършвахме с апарат „НОМОТН-2002, Rhino“ (Medezinelektronik GmbHs). Риноманометричният апарат е предназначен за предна активна риноманометрия.

Изследването провеждахме в седнало положение на пациента. Предварително избирахме адекватния размер назална олива, която се поставя в ноздрите. Първо извършвахме адаптативно изследване - пет спокойни вдишвания и издишвания за едната носна кухина, след което чрез натискане на специален бутон се сменя автоматично изследваната носна кухина. След тренировката пристъпвахме към същинското изследване, като апарата автоматично избира средните аритметични стойности от пет вдишвания и издишвания и ги представя графично на диаграма (ринограма). За всяка ноздра значимия поток се измерва в милилитри за секунда при инспирация и експириум при налягане от $150 \mathrm{~Pa}$. Пациентите с изкривена носна преграда изследвахме преди и десет минути след деконгестия. Постоперативно изследването извършвахме на 30 ден и на третия месец след отзвучаване на възпалителните промени в носната кухина.

\section{Резултати и обсьждане}

I. При клинично здравите пациенти (72 - 35 мъже и 37 жени) се получиха следните риноманометрични резултати:

При 53 (73,6\%) с нормални риноманометрични показатели:

- при 24 жени и 29 мъже кривите на ринограмата бяха гладки, симетрични за двете носни кухини.

При налягане от 150 Ра (Паскала) за инспириум и експириум разликата в обемите на въздушния поток не надхвърляше $20 \mathrm{ml} / \mathrm{sec}$.

Показателите при мъжете бяха между 300 и 490 $\mathrm{ml} / \mathrm{sec}$. за инспириум. При жените между 200 и $400 \mathrm{ml} / \mathrm{sec}$.

Съотношението между инспириум за двете носни кухини ( $\mathrm{SQ}=\mathrm{V} \sin / \mathrm{Vdec}$.) не надхвърляше 1,3 до 1,5 .

Промяната в обемите при инспириум за едната носна кухина $(\Delta \mathrm{V}=\mathrm{V} 300 / \mathrm{V} 150)$ от 150 Ра до 300 Ра бе над $40 \%$ до $100 \%$.

При 19 (26,4\%) се получиха неочаквани (ненормални) риноманометрични резултати :

- при 13 жени и 6 мъже кривите на ринограмата за двете носни кухини бяха с неравен ход и несиметрични.

При налягане от 150 Ра обемът на въздушния поток за инспириум и експириум бяха 100 и 250 
$\mathrm{ml} / \mathrm{sec}$ при мъжете и 50 и $150 \mathrm{ml} / \mathrm{sec}$ за жените. Съотношението при инспириум между двете носни кухини (SQ) надхвърляше 1,5 . Промяната в обемите при инспириум $(\Delta \mathrm{V})$ за едната носна кухина от $150 \mathrm{~Pa}$ до $300 \mathrm{~Pa}$ бе между $25 \%$ и $70 \%$. След деконгестия при всички се получи подобрение, но без да се стигнат нормалните стойности.

II. Преоперативно при 102 пациенти с девиирана носна преграда се получиха следните резултати :

1. 78 (46 мъже и 32 жени -76,4\%) пациенти показаха ненормални ринограми.

Патологичните ринограми разделихме в следните групи по Bachmann (1992)

a) $\Delta \mathrm{V}=0-25 \%, \mathrm{SQ}=1,1-6, \mathrm{~V}=100-200 \mathrm{ml} /$ sec.

b) $\Delta \mathrm{V}=25-35 \%, \mathrm{SQ}=1,5-6, \mathrm{~V}=250-300$ $\mathrm{ml} / \mathrm{sec}$.

c) $\Delta \mathrm{V}=0-20 \%, \mathrm{SQ}=5-10, \mathrm{~V}=300-500 \mathrm{ml} /$ sec.

2. 24 (14 мъже и 10 жени - 23,6\%) пациенти показаха нормални ринограми.

Нормалните ринограми бяха със следните стойности :

$\Delta \mathrm{V}=35 \%-790 \%, \mathrm{SQ}=1,3, \mathrm{~V}=400-800 \mathrm{ml} /$ sec.

Следоперативни резултати:

От 78 пациенти с ринограми показващи обструкция се получиха следните резултати :

a) $\Delta \mathrm{V}=0-25 \%, \mathrm{SQ}=1,1-6, \mathrm{~V}=100-200$ $\mathrm{ml} / \mathrm{sec}$.

b) $\Delta \mathrm{V}=25-35 \%, \mathrm{SQ}=1,5-6, \mathrm{~V}=250-300 \mathrm{ml} /$ sec.

c) $\Delta \mathrm{V}=0-20 \%, \mathrm{SQ}=5-10, \mathrm{~V}=300-500 \mathrm{ml} /$ sec.

След деконгестия резултатите от измерванията се подобриха при 47 (63,5\%) от случаите, но нормални стойности достигнаха едва 10 (7,2\%) от случаите. Останалите достигнаха долните граници на риноманометричните данни на здравите пациенти. Това бяха пациенти при които девиацията се съпровождаше с хипертрофия на долни носни конхи. Тези резултати съвпадат с резултатите получени от Sipila, Suonpaа и Laippala (1994) при 193 изследвани преди септопластика.

1. Установи се, че при предни девиации инспириума е по затруднен от експириума.
2. При среди и задни девиации инспириум и експириум са еднакво затруднени.

3. Типични ринограми за девииран носен септум се установиха само при едностранна обтурация на носната кухина и то до четири години от предхождаща травма.

4. Девиации в предните отдели на носната кухина предизвикват по тежки носни обструкции. Същият ефект се получава и при допиращи се до латералната носна стена девиации.

5. Съчетани девиации с хипертрофия на долна носна конха довеждат до тежки затруднения в носното дишане.

Нашите резултати съвпадат с тези на Cole (1992), докато Huygen (1992) стига до извода, че местоположението на деформитета не оказва такова влияние върху носното дишане, колкото големината на деформитета.

Pinkpank (1986) отбелязва несъответствие между обективната риноманометрия и субективните оплаквания на пациентите и смята,че тя би трябвало да играе ограничена роля за оценка функциите на носа.

Sandman (1989) установява, че грешките при риноманометрия са между 13,6 до 14,1 кРа/сек. Според Maranta (1995) грешките при риноманометрия възлизат между 10 и 20\%. Gammert and Scherrer (1993), Maranta (1995) считат, че мунщуците поставени в носната кухина или в нейния вход довеждат до промяна на анатомичните особености на носа, физиологията му, както и във функциите на назалната валва. Влиянието на лицевата маска върху тези фактори е по слабо, поради което те я препоръчват, като метод на избор.

\section{Заключение}

Получените резултати от изследването на клинично здрави пациенти са близки до тези получени от други автори - Cole $(1989,1992)$ Bachmann (1992), Huygen, Klaassen, Wentges (1992). Ненормалните резултати получени при 26\% от изследваните без риноскопични данни за назална обструкция са също близки до тези на споменатите автори. Те обясняват това с неточност на методиката и го изтькват като неин недостатък. Според Maranta (1995) грешките при риноманометрия възлизат между 10 и $20 \%$. Не е рядко срещано явление пациент с оплаквания от затруднено носно дишане да има нормални риноманометрични измервания 
и обратно (Jones 1989, Eccles 1990, Naito 1995). Pinkpank (1986) отбелязва също несъответствие между субективните оплаквания на пациентите, риноскопичната находка и риноманометричните данни. Той стига до извода, че риноманометрията играе ограничена роля при оценка на носната проходимост. Повечето автори обясняват тези резултати със сложната анатомична архитектоника на носната кухина и нейната физиология и несъвършените технически възможности за изследването и до настоящия момент. Не винаги степента на оплакванията от обструкция в нос-

\section{Литература}

1. Cole P. Nasal and oral airflow resistors. Arch. of Otolaryngol.Head and Neck Surgery. 1992, 188, 8, 790-793.

2. Cole P., The Respiratory Role Of The Upper Airways. Moby Year Book, 1993, 1-147.

3. Cole P., The airflow resistans profile of healthy nasal cavities.,Rhinology, 1995, vol 33, 1, 10-14.

4. Бояджиев Г. Обективни методи за изследване на носното дишане в норма и патология. Дисертация. София 2007 г.

5. Вичева, Д. Измерване на носа с акустична ринометрия. Медицински преглед. 2004, Vol. XL; 3: 69-73.

6. Вичева, Д. Функционално носно дишане. Международен Бюлетин по оториноларингология, 2005, 2: 43-47.

7. Бенчев Р. Хирургична корекция на затрудненото носно дишане след риносептопластика. Оториноларингология 2005/3: 28-31

8. Бенчев Р. Затрудненото носно дишане след ринопластика. Оториноларингология 2005/4: 33-36 ното дишане е адекватна на измерените стойности при риноманометрия Jones, Lanser, Stevens (1987), Eccles (1983, 1987) Yavin et al. (1997). Lund (1991) смята, че носното съпротивление и усещането за носен поток са напълно различни и самостоятелни неща. Yaniv (1997), така и други автори отричат клиничната стойност на риноманометрията.

Въпреки това предната активна риноманометрия е една от най-често използваните методики за оценка на носното дишане.

9. Бенчев Р., Бояджиев Г. Риноманометрия - метод за обективно изследване на носното дишане. Оториноларингология 2004: 60-64.

10. Недев П. Външен достъп при риносептопластика. Оториноларингология 1999; III: 38-44.

11. Недев П. Хирургично лечение на затрудненото носно дишане дължащо се на девиирана носна преграда. Дисертация София 2003.

12. Pinkank A., Beziehungen zwiscen Selbsteinstufung der Nasenatmung, Rhinoscopie und Rhinomanometrie, H.N.O., 1986, 34, №5, 194-197

13. Bachmann W: Differential diagnosis in patients with nasal obstruction: rhinomanometric indications for surgery, Facial Plastic Surg, 1990; 7:274.

14. Hirschberg A and others: The airflow resistance profile of healthy nasal cavities, Rhinology 33:10, 1995 